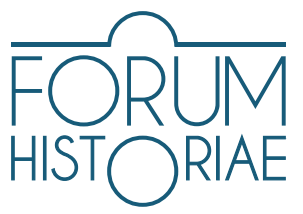

\title{
Italian-Hungarian Support for the Internal Macedonian Revolutionary Organization (IMRO): A Case Study on the Hungarian Role in Italy's Aspirations towards the Bal- kan Region during the Interwar Period
}

\author{
Petra Hamerli
}

\begin{abstract}
HAMERLI, Petra. Italian-Hungarian Support for the Internal Macedonian Revolutionary Organization (IMRO): A Case Study on the Hungarian Role in Italy's Aspirations towards the Balkan Region during the Interwar Period. The disintegration of the Austro-Hungarian Monarchy after the Great War changed the international order of Europe as new states were born and old ones had to adapt to transformed environments. Even the directives of the Paris Peace Conference could not satisfy every claim and the many expectations of all European countries. Regarding the victorious powers, the most unsatisfied with the new order of Europe was undoubtedly Italy. On one hand, it had joined the Entente powers due to the promise of gaining territories, including Istria and the Dalmatian Coast, which was eventually given to the Kingdom of Serbs, Croats and Slovenes (from 1929 Yugoslavia), based on the principle of national self-determination. On the other hand, the main aim of Italian foreign policy regarding Europe - especially after Benito Mussolini came to power - was to gain influence in the Balkans, Central-Europe, and the Mediterranean. Yugoslavia posed an obstacle to these goals merely by its existence. As the Italian politicians were aware, Hungary - absent two thirds of its historical territory and losing the Voivodinian part to Yugoslavia - was also interested in weakening the South-Slavic state. The Italian government approached Hungarian leaders and offered their support of Hungary's revisionist claims. This led to strong cooperation between the two states, which included the common support of separatist movements organized within Yugoslavia, (Ustasha, Internal Macedonian Revolutionary Organization IMRO). This case study presents the Italian-Hungarian support given to the IMRO which is a lesser known chapter in the history of the Interwar Period.
\end{abstract}

Keywords: Hungarian-Italian Relations, Separatism in Yugoslavia, IMRO, Italian Fascist Foreign Policy, Hungarian Foreign Policy in the Interwar Period

DOI: https://doi.org/10.31577/forhist.2021.15.1.3

\section{Yugoslavia's Role in Hungarian-Italian Relations}

$\mathrm{O}$ n 5 April 1927, the Hungarian and Italian prime ministers, István Bethlen and Benito Mussolini, signed the Italian-Hungarian Treaty of Friendship, Conciliation and Arbitration, which strengthened cooperation between the two states. The published part of the treaty seemed to be a typical, generic document on diplomatic relations between the two countries, but a secret clause declared that the Hungarian and Italian governments would harmonize their policies regarding the issues in which both of them were interested. ${ }^{1}$ In practice, this section clearly meant that in the future Italy would support Hungarian revisionism while Hungary would assist the Italian manoeuvres against the Kingdom of Serbs, Croats and Slovenes, later Yugoslavia. ${ }^{2}$

1 Magyar Nemzeti Levéltár Országos Levéltára - National Archive of Hungary (MNL OL), Budapest, K 64. 24. csomó. 23. tétel. 1927. 73 res. pol. 1927.

2 The South-Slavic state was founded in 1918 under the name "Kingdom of Serbs, Croats and Slovenes", but the term Yugoslavia was in common use, and in 1929 became official. In order to use the terms sequentially and for better understanding of related literature, the majority of historians use the term "Yugoslavia" in dis- 
This shows that one of the key elements of Hungarian-Italian relations, mainly according to the Italian point of view, was the "Yugoslavian question", i.e. Italian policy towards Yugoslavia. To understand Italian-Yugoslavian relations of the Interwar Period, the Treaty of London signed on 26 April 1915, needs to be mentioned first. In this secret agreement, the Entente Powers, namely France, Great-Britain and Russia, promised the area of South Tyrol, (Trentino), with Brenner Pass, Trieste, the Italian-inhabited part of the Dalmatian Coast and the Eastern part of Istria to Italy. Besides this, the treaty ensured Italy the sharing of the German colonies and guaranteed protectorate over Albanian territories in the case of Italian intervention into war in alliance with the Entente. ${ }^{3}$ As the Italian government considered participation as an excellent opportunity to strengthen Italy's position within international ranks, Prime Minister Antonio Salandra decided to intervene. The problem that later caused in the conflict with Yugoslavia was that the Serbian government - an ally of the Entente too - declared that in case of victory, it would claim the territory of Bosnia and Herzegovina, the Voivodinian Region, Croatia, Slovenia, Dalmatia and Istria. ${ }^{4}$ As we can see, the latter two territories were partly promised to Italy as well. At the Paris Peace Conference, (1919), while arguing the ethnical principles laid out by American President Thomas Woodrow Wilson, decision-makers gave the major part of the two regions to the Yugoslavian state, which made Italy feel that its allies had betrayed them. In addition, the National Council of Fiume, (nowadays Rijeka), turned to the Italian Prime Minister, Vittorio Emanuele Orlando, with a petition expressing the willingness of the Fiumean-Italian citizens to join Italy. ${ }^{5}$ As a result, the Italian delegation at the Paris Peace Conference claimed the city of Fiume as well, which meant another contested point with Yugoslavia.

From the Italian point of view, these territorial conflicts originated from the fact that the Italian government aimed at strengthening its influence in the Balkans, the Danubian region and the Mediterranean, (including Northern-Africa), and gaining hegemony in the Adriatic. ${ }^{6}$ As well-known Italian historian Renzo De Felice writes in his monumental biography on Fascist leader Benito Mussolini, the Italian foreign policy goals can be summarized in two words: sicurezza and espansione (security and expansion); security in Central Europe (the Balkans and Danubian region), and expansion towards the Mediterranean and Africa. ${ }^{7}$ Looking at the map of Europe in the Interwar Period, it is evident that Yugoslavia, merely by its existence, meant an obstacle to Italy in realizing these aspirations and therefore weakening Yugoslavia's position was of primary interest to the Italian government.

In 1922, Mussolini was elected prime minister of Italy, which meant the beginning of the Fascist regime that shaped the Italian political system for more than two decades (1922-1943). During the first years, Mussolini concentrated on consolidating his power so he focused on domestic affairs rather than on foreign policy. The result was that in the first half of the 1920s, there were no significant changes in the Ministry of Foreign Affairs and the famous General Secretary of Foreign Affairs of the Liberal Era, Salvatore Conta-

cussing events before 1929 as well. I also follow this tendency.

3 MOSCA, Rodolfo (ed.) I Documenti Diplomatici Italiani. Quinta serie, Volume 3. Roma : Libreria dello Stato, 1953, Document 470, The Treaty of London, 26 April 1915.

4 HORNYÁK, Árpád. Magyar-jugoszláv diplomáciai kapcsolatok, 1918-1927. Novi Sad : Forum Kiadó, 2004 , p. 11.

5 MOSCA, Rodolfo (ed.) I Documenti Diplomatici Italiani. Settima serie, Volume 4 - 16. Roma : Libreria dello Stato, 1953, Document 134, Orlando to Bonin Longare, 13 November 1918. (Henceforward: DDI, Sesta serie).

6 CAROCCI, Gianpiero. La politica estera dell'Italia fascista. Bari : Editore Laterza, 1969, pp. 13-14.

7 DE FELICE, Renzo. Mussolini il duce. Vol. I. Gli anni del consenso, 1929-1936. Torino : Einaudi, 1974 , p. 347. 
rini, was able to keep his position in the ministry until 1926. He aimed at strengthening Italy's international position but believed that the establishment of sufficient relations with neighbouring countries was just as important. In order to develop a peaceful relationship with the Yugoslavian government, Contarini promoted an Italian-Yugoslavian agreement (the Treaty of Rome, 1924), to find compromises in their conflicts. In this pact, the government of Belgrade recognized the Italian annexation of Fiume. This act can be considered the last success of Contarini ${ }^{8}$ as after some disputes he resigned (1926). A year before in 1925, a young Fascist, Dino Grandi, was appointed to Vice-Secretary of Foreign Affairs. Then in 1929, he became Minister of Foreign Affairs directing the institution for seven years until 1932. Grandi's and Mussolini's opinions were quite different on some questions but regarding the Yugoslavian policy, their thoughts were consistent: Yugoslavia's position had to be weakened. ${ }^{9}$ This was not a new idea within Italian foreign policy, first appearing in $1918 .{ }^{10}$ According to Mussolini's point of view, a possible way of diminishing Yugoslavia was to encircle it by those states which - like Italy - had conflicts with the South-Slavs. To realize this, he counted on the assistance of Albania, Bulgaria, Romania and Hungary ${ }^{11}$, as these countries also had territorial conflicts with Yugoslavia.

From our point of view, it is important to see what Hungary could have benefited from support of the anti-Yugoslavian aspirations of Italy. With the Treaty of Trianon signed on 4 June 1920, Hungary lost two thirds of its historical territory, and - besides Austria, Czechoslovakia and Romania - Yugoslavia claimed and received former Hungarian lands, namely the Voivodina and Medjimurje areas, (the independence of Croatia from Hungary had been recognized earlier by the Hungarian government). As a result, the main aim of Hungarian foreign policy was a revision of the treaty and for this to happen, the support of the victorious powers was necessary. In 1921, a new prime minister was elected, István Bethlen, (1921-1931), who conceptualized Italy's role in Hungarian diplomacy. The main idea was that Hungary was in danger after losing the Carpathians as the countries of the Little Entente - an organization formed in 1920-1921 by Czechoslovakia, Romania and Yugoslavia with the aim of obstructing revision of the treaty and a Habsburg restoration - and the Soviet Union encircled Hungary, which remained without any defence. That is why, argued Bethlen, the revision was of fundamental interest to the Hungarian government. Due to the abovementioned reasons, Italy was also unsatisfied with the Versaille System and was not interested in Slavic hegemony in Central Europe, therefore the Italian government could be considered as a natural ally of Hungary in gaining the treaty revision. Though, still citing Bethlen's point of view, Italy itself was not potential enough to gain practical support for realizing the Hungarian aspirations, so in the long run, a HungarianItalian-German block had to be established. ${ }^{12}$

8 DI NOLFO, Ennio. Mussolini e la politica estera italiana (1919-1933). Padova : Cedam, 1960, pp. 46-48.

9 LEFEBVRE D'OVIDIO, Francesco. L'Italia e il sistema internazionale. Dalla formazione del Governo Mussolini alla Grande depressione (1922-1929) Volume 1. Roma : Edizioni di Storia e Letteratura, 2016, p. 214.

10 For this, a plan was developed in 1918 that aimed to encircle the Yugoslavian state by its enemies and the promotion of its disintegration with the help of supporting separatist groups of Yugoslavia. The plan - despite that it was probably not created by him - was named after general Pietro Badoglio, the chief of staff of the Italian army. BUCARELLI, Massimo. Mussolini e la Jugoslavia 1922-1939. Bari : B. A. Graphis, 2006, p. 11.

11 HORNYÁK 2004, p. 27.

12 ORMOS, Mária. Bethlen koncepciója az olasz-magyar szövetségről (1927-1931). In Történelmi Szemle, 1971, No. $1-2$, pp. 133-156. 
Similarly to Bethlen, Mussolini was aware of the significance of Germany amongst the European international system, but initially he did not consider the possibility of an ItalianGerman alliance. Actually, Germany meant a possible rival in the Danubian Basin, the Balkans and in Africa as well, therefore, Mussolini aimed at establishing influence in these territories before Germany was able to strengthen its geopolitical position. Among these territories, Africa took priority in Mussolini's mind so he made some compromises in the Danubian-Balkan region. ${ }^{13}$ The Hungarian political élite did not take into consideration these facts and hence overvalued Hungary's significance in Italian foreign policy. ${ }^{14}$

In 1926, Mussolini's target - as we could see - was to establish influence in Central Europe, the first step in realizing his full ambitions. For this, the cooperation of Hungary was necessary and Italy, represented by Dino Grandi and Ercole Durini di Monza, the Italian Ambassador to Budapest, offered to negotiate with the Hungarian government. By that time, Hungarian-Yugoslavian negotiations from the early 1920s had failed so Hungarian politicians were quick to sign a treaty of friendship with Italy. ${ }^{15}$ For Mussolini, this treaty was a piece of the encirclement of Yugoslavia. ${ }^{16}$ The Italian-Hungarian Treaty of Friendship was preceded by a series of other agreements made by Italy with the anti-Yugoslavian states. The first was a pact of friendship and security with Albania signed in Tirana, (the First Treaty of Tirana). This declared that the two states would support each other to preserve Albania's political, judicial and geographic status quo. ${ }^{17}$ One year later in 1927 , Italy and Albania signed the second Treaty of Tirana, which was more obviously anti-Yugoslavian than the first one. As we have already mentioned, for realizing the encirclement of the South-Slavic state an alliance with Romania was necessary so in September 1926, the Italian-Romanian Treaty of Friendship on the two countries cooperation was signed. In the case of a conflict initiated by a third state, neutrality was agreed. Cooperation was also necessary from Bulgaria ${ }^{18}$, to which the road led through the Internal Macedonian Revolutionary Organization, which was founded with the aim of reaching autonomy for Macedonia or within a South-Slavic federation, or within Bulgaria. ${ }^{19}$

\section{Support for the Internal Macedonian Revolutionary Organization}

The IMRO, in Macedonian, "Vnatrešna Makedonska Revolucionarna Organizacija, VMRO", was founded in 1893 and led by Todor Alexandrov and Aleksandar Protogerov with the abovementioned goal of gaining the independence of Macedonia. The reason for establishing this organization was that in the late 1800s four states, Bulgaria, Serbia, Greece and Romania, sought to acquire the territory of Macedonia as it did not have fixed frontiers. The region was strategically important because of Thessaloniki's harbour and the basin of the Vardar and Strumica rivers. ${ }^{20}$ As the $19^{\text {th }}$ century was the era of nationalism in Europe, and - like other non-independent nations of the continent - the Macedonians

13 HORVÁTH, Jenő. Olaszország Kelet-Közép-Európa politikája 1918-tól napjainkig. In Grotius 2006, p. 20, http:// www.grotius.hu/doc/pub/YWJMAR/horvath_jeno_grotius_e-konyvtar_2006.pdf [last viewed on 20 June 2020]. A good example for that is the Italian-Yugoslavian treaty of friendship of 1937.

14 BRECCIA, Alfredo. La politica estera italiana e l'Ungheria 1922-1933. In Rivista di Studi Politici Internazionali, 1980, No. 1, pp. 93-112.

15 HORNYÁK 2004, pp. 248-249.

16 BUCARELLI 2006, p. 11.

17 JUHÁSZ, Gyula. Magyarország külpolitikája 1919-1945. Budapest : Kossuth Kiadó, 1988, p. 105.

18 HORNYÁK 2004, pp. 236-237.

19 JELAVICH Barbara. A Balkán története. II. kötet. 20. század. Budapest : Osiris Kiadó, 1996, p. 87.

20 JELAVICH 1996, pp. 83-84. 
wanted sovereignty so they decided to found the IMRO with the slogan "Macedonia for Macedonians". The IMRO could imagine the independence of Macedonia in one of two ways; on one hand, as a nation-state within a South-Slavic federation, and on the other as an autonomous region within the Bulgarian state. In the case of the latter, the organization could exercise some influence on the Bulgarian Government. ${ }^{21}$ The IMRO began to infiltrate into international affairs after the Revolution of Ilinden in 1903, which sought the independence of Macedonia from the Ottoman Empire. ${ }^{22}$

In 1912, the Bulgarians, Greeks and Serbs made bilateral agreements on helping each other in an eventual war against the Ottoman Empire. They settled on the division of Macedonia amongst each other and besides this, Greece and Serbia made a second agreement on the division of the Albanian territory as well, and then the first Balkan War broke out. After the war, the Great Powers decided to create an independent Albania. The Greeks and Serbs wanted compensation by acquiring the Bulgarian part of the Macedonian territories, which led to the second Balkan War in 1913. It was closed by the Peace Treaty of Bucharest, which left only Pirin-Macedonia to Bulgaria, while Greece got Aegean-Macedonia and Serbia gained Vardar-Macedonia ${ }^{23}$, so the region was divided into three parts.

In 1914, when the first World War started, Bulgaria decided on neutrality at the beginning. As both the Entente States and the Central Powers desired to involve the state into the war, the Bulgarian Government made claims to the whole of Macedonia in exchange for intervention. The Central Powers, namely the Austro-Hungarian Monarchy and Germany, promptly agreed on this promise to Bulgaria, which joined them in $1915 .{ }^{24}$ During the war, the Macedonians continued their campaign for autonomy in neutral Switzerland ${ }^{25}$, where they founded the monthly paper Macédonie. As a member of the Central Powers, Bulgaria lost the war. It was not able to obtain the promised territory and Macedonia stayed divided. ${ }^{26}$ The Macedonian question was not resolved and the activities of the IMRO continued.

The Yugoslavian State formed after the first World War aimed to unify the South-Slavic people living in Central Europe under the domination of the Serbian Karađorđević Dynasty. The new state was not ethnically homogenous. About a dozen ethnic groups lived together in the country differing from each other in both mother language and cultural heritage, and thus religion, traditions and history. The dominant Serbian nation made up only $40 \%$ of the total inhabitants, there were also Croats, Slovenes, Macedonians, Dalmatians, Bosnians, Hungarians, Germans, Romanians, Italians and Albanians comprising the population of the country. ${ }^{27}$ Among the Croats - the second largest group after the Serbs - and the Macedonians - who had already founded a national organization - the idea of separatism appeared just after the formation of Yugoslavia. Hungary and Italy supported both movements, but as I have already examined the Italian-Hungarian support for Croatian separatism in detail in two previously published studies of mine ${ }^{28}$, I will focus here on the IMRO.

21 JELAVICH 1996, p. 87.

22 ROSSOS, Andrew. Macedonia and the Macedonians. Stanford : Hoover Institution Press, 2008, p. 99.

23 FRUSETTA, James. Bulgaria's Macedonia: Nation-building and State Building, Centralization and Autonomy in Pirin Macedonia, 1903-1952. PhD thesis, University of Maryland, College Park, 2006, p. 156.

24 FRUSETTA 2006, p. 157.

25 ROSSOS 2008, p. 128.

26 ROSSOS 2008, p. 129.

27 ORMOS Mária. Merénylet Marseille-ben. Budapest : Kossuth Kiadó, 1984, p. 16.

28 HAMERLI, Petra. Magyar-olasz együttmüködés a horvát szeparatisták támogatásában 1927-1934. In Századok, 
The other process of weakening Yugoslavia was promotion of its inner, ethnic conflicts ${ }^{29}$, which actually meant supporting the separatists. As a first step, in 1924 Hungarian politicians thought to get in touch with the leaders of the IMRO. Ambassador András Hory ${ }^{30}$ wrote in his memoir: "In the current situation, we have to get in touch with the enemies of our enemies and cordialize with them, he [Kálmán Kánya, deputy of the Minister of Hungarian Foreign Affairs] said. He turned my attention to the dissatisfaction of the Macedonians and ordered to me to cordially welcome the Macedonians who may turn to me and from who I can get valuable information." ${ }^{31}$ This shows Hory remembering Kánya’s suggestion, which in my opinion gives an exact summary of the IMRO's role in Hungarian foreign policy. Relations with the IMRO could have been beneficial for Hungary for two reasons; on one hand, the IMRO's activity could weaken the Yugoslavian State, which was one of the members of the Little Entente, and on the other hand, the Macedonians could provide precious information on Yugoslavian policy.

In 1925, Dr. Ewald Ammende, a German politician living in Estonia, proposed the organization of a congress at the Paris Peace Conference ${ }^{32}$ where every minority group in Europe could represent themselves and express their opinions on the cultural autonomy and minority rights that had been agreed on by the decision-makers in Paris. ${ }^{33}$ Concerning the Macedonians, Ammende suggested not to send any from Bulgaria as they had been engaged in acts of terror, but to represent themselves with Macedonians from other countries. On 19 May 1927, Ammende arrived in Sofia to meet János Kiss, the councillor of the Hungarian embassy in Bulgaria. They negotiated on the Macedonian question and Kiss offered mediation between Ammende and the Macedonians. The problem was that after seeing the proposal of Ammende, the Macedonians thought he wanted to exclude them from the congress. ${ }^{34}$ This led to misunderstandings with Hungarian politicians as well so the new deputy of the Minister of Foreign Affairs, Sándor Khuen-Héderváry, ordered a suspension of the mediation between Ammende and the Macedonian group..$^{35}$ After this, in August 1927, one of the leaders of the IMRO, Naum Tomalewski, travelled to Budapest where he visited Khuen-Héderváry and the Minister of Foreign Affairs, Lajos Walko, to personally give a report on the situation of the Macedonians. ${ }^{36}$ With these negotiations, Hungary got in touch with the IMRO.

Although the scientific literature says that Italy supported the IMRO from $1923^{37}$, archival sources and diplomatic documents reveal that Mussolini obligated himself to help the Macedonian organization only in 1927. His motivation was that Bulgarian Prime Minister Andrei Liapchev had communicated to Renato Piacentini, the Italian ambassador to

2017, No. 4, pp. 879-904; HAMERLI Petra. The Hungarian-Italian Support of Croatian Separatism between 1928 and 1934. In West Bohemian Historical Review, 2015, No. 1, pp. 51-70.

29 HORNYÁK 2004, p. 27.

30 In 1924 András Hory was the Hungarian ambassador in Belgrade, then from 1927 to 1934 in Rome.

31 HORY, András. Bukaresttől Varsóig. Budapest: Gondolat Kiadó, 1987, p. 131; My own translation, (as are all of the citations).

32 The Peace Treaties signed at the Paris Peace Conference of 1919 included orders for the protection of minorities, which actually was not kept by the successor States.

33 EILER, Ferenc. Nemzetközi kisebbségi kongresszusok a két világháború között. In Regio - Kisebbség, Politika, Társadalom, 1996, No. 3, pp. 137-164.

34 MNL OL, K 64. 24. csomó. 16. a tétel. 49 pol. 1927. Kiss to Walko, 25 May 1927.

35 MNL OL, K 64. 24. csomó. 16. a tétel. Telegraph 5920. Khuen-Héderváry to Kuhl, 2 July 1927.

36 MNL OL, K 64. 24. csomó. 16. a tétel. 79 pol. 1927. Kiss to Walko, 19 August 1927.

37 SADKOVICH, James. Opportunismo esitante: la decisione italiana di appoggiare il separatismo croato: 19271929. In Storia Contemporanea, 1985, No. 3, pp. 401-426. 
Sofia, that Bulgaria would have appreciated if the Italian delegates in the League of Nations sometimes protected Macedonian interests in front of its Council. ${ }^{88}$ Italy was interested in having Bulgaria among its allies so Mussolini took the opportunity to strengthen Italian-Bulgarian relations, declaring that "from nowadays [from 1927] the Macedonians have the most cordial friendship of Italy" ${ }^{39}$ In this letter to Piacentini, Mussolini explained that the IMRO was appropriate to obstruct the Yugoslavian-Bulgarian approach and that is why the organization deserved special attention and support. ${ }^{40}$ Thus Mussolini ordered Piacentini to contact the Macedonians, especially Tomalewski, and gain information from him. ${ }^{41}$

After that, Piacentini met Tomalewsky more times but he did not approach other Macedonian leaders ${ }^{42}$, as Italy agreed with the statement of the other Great Powers, (France, Great Britain), which thought that the terror acts of the IMRO had endangered peace in Europe $^{43}$ as the Macedonians - especially the fraction of IMRO led by Ivan Mihailov ${ }^{44}$ - had committed several crimes not only against Bulgarian politicians, but also against civilians. News of these cruelties was dispersed in the world press and some European public figures voiced their objections. For example, the famous French writer Henri Barbusse turned to the League of Human Rights with a petition in 1928 to direct the organization's attention towards the IMRO's actions ${ }^{45}$, while the British government - as we will see - expressed its condemnation in a memorandum sent to Bulgarian leaders. Nevertheless, Italian politicians were aware of the fact that the Macedonian question represented the most vulnerable point for Yugoslavia. ${ }^{46}$ Italy followed a policy of sacro egoismo - saint egoism - where the weakening of Yugoslavia for them was much more important than peace in Europe and avoiding terrorism. At one of the Piacentini-Tomalewski meetings, Tomalewski suggested to Italy to communicate with the Croatian separatists as well and he asked for information about the Italian-Yugoslavian relations, but Piacentini did not say anything about it to the Macedonian leader ${ }^{47}$ because he did not wish to discover that the IMRO was actually an instrument for the realization of Italy's anti-Yugoslavian ambitions.

In January 1928, Tomalewski visited Hory as well. During the meeting, Tomalewski explained that the Macedonians had realized that Italy had been seeking to use them for its own purposes. He declared that the Macedonians would participate in a causal ItalianYugoslavian conflict only if the Italians first convincingly supported the IMRO's aims. ${ }^{48}$ Hory tried to persuade Tomalewski to keep in touch with Italy, which makes it evident that Hungary's role of mediator helped to establish relations between Italy and the IMRO. ${ }^{49}$

38 DDI, Settima serie, Vol. 5, Document 369, Piacentini to Mussolini, 23 August 1927.

39 DDI, Settima serie, Vol. 5, Document 446, Mussolini to Sola, 3 october 1927.

40 DDI, Settima serie, Vol. 5, Document 446, Mussolini to Sola, 3 october 1927.

41 Archivio Storico Diplomatico del Ministero degli Affari Esteri - Historical Archive of the Italian Ministry of Foreign Affairs (ASMAE), Rome, Affari Politici 1919-1930. Busta 921. Fasc. Questione Macedone. No. 1487/358 R. Mussolini to Piacentini, 14 November 1927.

42 ASMAE, Affari Politici 1919-1930. Bulgaria. Busta 924. Telegramma 1642. Piacentini to Mussolini, 19 March 1928.

43 ASMAE, Affari Politici 1919-1930. Bulgaria. Busta 921. Telegramma 7244/1366. Bodrero to Mussolini, 12 October 1927.

44 See details in the next chapter of this paper.

45 ORMOS 1984, pp. 45-46.

46 ASMAE, Affari Politici 1919-1930. Bulgaria. Busta 921. Telegramma 7244/1366. Bodrero to Mussolini, 12 October 1927.

47 DDI, Settima serie, Vol. 6, Document 244, Piacentini to Mussolini, 11 April 1928.

48 MNL OL, K 64. 29. csomó. 16. a tétel. 7 pol./ 1928. Hory to Walko, 24 January 1928.

49 ORMOS 1984, p. 46. 
All in all, the Hungarian and the Italian political elite considered the IMRO to be the major obstacle of cordial relations between Bulgaria and Yugoslavia, and as they were both interested in hindering this approach, they supported the Macedonian organization. Additionally, the two states could gather precious information from the IMRO leaders about Yugoslavian policy. On the other hand - as the IMRO was famous for its terrorist acts - cooperation with the IMRO could be very compromising for its foreign supporters and that is why both Hungary and Italy were anxious about the activities of the IMRO and payed it special attention..$^{50}$ In 1928 , their anxiety was confirmed.

\section{Compromising Acts and the End of Support}

On 8 July 1928, one of the IMRO's leaders, Aleksandar Protogerov, was murdered and another Macedonian leader, Ivan "Vancho" Mihailov was suspected to be the killer. Hungarian councillor János Kiss reported that this suspicion could be verified by some well-known facts. First of all, witnesses confirmed that Mihailov had explained that he would take responsibility for the assassination and revealed his motivation at the congress of the IMRO. He said that the killing of Protogerov was justified revenge as in 1924, Protogerov had played a significant role in the assassination of Todor Alexandrov, Mihailov's predecessor. Secondly, Kiss continued his report, some politicians thought that the Bulgarian Secretary of War, Ivan Valkov, would have had a part in the assassination of Protogerov but in councillor Kiss' opinion, Valkov certainly could not have ordered the murder of Protogerov, but it could be possible that Valkov had given moral and financial support as the relationship between Valkov and Protogerov was bad. This idea could be confirmed by the fact that Valkov did not order an arrest warrant for Mihailov, and just before it happened Valkov left for an "unnamed place". Members of the IMRO blamed Mihailov and his ambitions for the killing $^{51}$, Italy completely accepted the explanation of Mihailov. ${ }^{52}$

After the death of Protogerov, the IMRO broke into two factions: The Protogerovists led by Tomalewski were federalists who imagined the autonomy of Macedonia within a South-Slavic federation and the Mihailovists, also called centralists, who sought to unify the Macedonian territories within Bulgaria creating a "state in a state", naturally they enjoyed the official support of the Bulgarian government. ${ }^{53}$ Actually, Mihailov thought about the possibility of independence as well, which can be seen in a Hungarian document written by Kiss: "The group of Mihailov actually aims at its [Macedonias] full independence from the Bulgarian government. It clearly points out that Bulgaria does not have any more right to Bulgarian-Macedonia than Yugoslavia has for Serbian-Macedonia, or Greece has for Greek-Macedonia." ${ }^{54}$ However, Mihailov was aware of the fact that total separatism could not be realized so he showed his approval for autonomy within Bulgaria.

Regarding to the two fractions, Kiss said that the Protogerovists were stronger but the Mihailovists more determined. The councillor had the impression that the Macedonians regretted not only the death of Protogerov, but also the fact that this case undermined

50 HAMERLI, Petra. Magyar-olasz diplomáciai kapcsolatok és regionális hatásaik, 1927-1934. Doktori és Habilitációs Értekezések. Budapest: Fakultás Kiadó, 2018, p. 125.

51 MNL OL, K 64. 29. csomó. 16. a tétel. 83 pol./1928. Kiss to Walko, 20 July 1928.

52 ASMAE, Affari Politici 1919-1930. Bulgaria. Busta 924. Telegramma 985/219. 24 August 1928.

53 JELAVICH 1996, p. 154.

54 MNL OL, K 64. 29. csomó. 16. a tétel. 118 pol. 1928. Kiss to Walko, 26 October 1928. 
the international authority of the IMRO. ${ }^{55}$ The Bulgarian state, as the main supporter of the IMRO was in a grave situation too. On one hand, the actions of the IMRO obstructed the Bulgarian-Yugoslavian approach and on the other hand, the neighbour states began to treat Bulgaria as an enemy which resulted in political isolation..$^{56}$ As a consequence, the effect that the IMRO had on the Bulgarian Government decreased and without this influence, Bulgaria was ready for an alliance with Yugoslavia. This meant that the main obstacle of a Serbian-Bulgarian approach had weakened, which made Hungary anxious. ${ }^{57}$

After the murder of Protogerov, the British Government demanded the tightening of control of the IMRO's activity from Bulgaria in a memorandum written on 3 August 1928 to the Government of Liapchev. ${ }^{58}$ Great Britain called on the other Great Powers to join the memorandum but the Italian politicians really did not want to get involved in the domestic affairs of Bulgaria. Their real motivation for rejection ${ }^{59}$ was certainly, as Piacentini explained in one of his letters, that the intervention "would hurt the feelings of our Macedonian friends because they would not understand why we Italians take solidarity with the plans of France, England, and especially of Belgrade against the IMRO".60 Still, the Bulgarian Minister of Foreign Affairs, Atanas Burov, was ready to take measures to break up the IMRO because his British colleague, Austen Chamberlain, had promised earlier a loan for paying reparations laid out in the Peace Treaty of Neuilly after the first World War, (1919), and the memorandum declared that this loan would not be provided if Bulgaria did not fulfil what Great Britain was asking for concerning the IMRO. ${ }^{61}$

After the assassination of Protogerov, Hungary had relations with both of the factions but at the beginning Italy approached only the Protogerovists. In August, Tomalewski asked for financial support from Italy to consolidate the IMRO. He negotiated with Dino Grandi, explaining to him that he would not have asked for such a large loan from Italy - two million Italian Lira - if the party had not broken up. ${ }^{62}$ In the meantime, Piacentini made a report on his impressions where he explained that the leaders of the two Macedonian divisions were unable to negotiate with each other seriously because their plans and ideas were so different that unity and cooperation was impossible. ${ }^{63}$ For example, as Italian ambassador to Vienna Giacinto Auriti wrote to Mussolini, the Mihailovists planned to get rid of Burov, who was prepared for a Bulgarian-Yugoslavian accord as France and Great Britain had wished. Contrary to Mihailov, the Protogerovists were disposed to support Burov. The Italians thought that Tomalewski would be able to manage these conflicts ${ }^{64}$ and that is why Italy assisted Tomalewski.

In December a fiducial of Burov, Bulgarian delegate Ivan Petrov, visited Piacentini. Petrov told him that in fact Burov had been an anti-Serbian patriot, but he wanted peace so he was forced to consolidate Bulgaria’s relations with Yugoslavia. Besides this, Burov wanted cor-

55 MNL OL, K 64. 29. csomó. 16. a tétel. 83 pol. 1928. Kiss to Walko, 20 July 1928.

56 JELAVICH 1996, p. 154.

57 MNL OL, K 64. 29. csomó. 16. a tétel. 83 pol. 1928. Kiss to Walko, 20 July 1928.

58 DDI, Settima serie, Vol. 6, Document 547, Mussolini to Piacentini, 11 August 1928.

59 ASMAE, Affari Politici 1919-1930. Bulgaria. Busta 924. Telegramma 4146/227. Mussolini to Piacentini, 11 August 1928.

60 DDI, Settima serie, Vol. 6, Document 538, Piacentini to Mussolini, 8 August 1928.

61 DDI, Settima serie, Vol. 6, Document 549, Mussolini to Piacentini, 11 August 1928.

62 DDI, Settima serie, Vol. 6, Document 587, Grandi to Mussolini, 25 August 1928.

63 ASMAE, Affari Politici 1919-1930. Bulgaria. Busta 924. Telegramma 5156/228. Piacentini to Grandi, 28 August 1928.

64 DDI, Settima serie, Vol. 6, Document 628, Auriti to Mussolini, 6 September 1928. 
dial relations with Italy too so he hoped that their representation was willing to assist him in front of the League of Nations in his efforts to make an accord favourable for the Serbs. ${ }^{65}$ Unfortunately, the documents do not reveal how Italy accepted Petrov's approach.

On 6 January 1929, as a "Christmas giff", Yugoslavian king Alexander I introduced dictatorship in his country in an attempt to resolve the ethnic conflicts. In October, he changed the name "Kingdom of Serbs, Croats and Slovenes" to "Yugoslavia" to emphasize the transnationality and unity of his empire. ${ }^{66}$ The official Belgrade press, Pravda, declared that the leaders of the IMRO should drop its separatist ambitions and their campaign against Serbians because the new regime made the stabilization of the Yugoslavian State possible. ${ }^{67}$

Even so, the IMRO continued to struggle for Macedonian independence and it helped the creation of a new separatist party in Yugoslavia. ${ }^{68}$ This was a Croatian party led by Ante Pavelić who enjoyed Mussolini's support and had founded the Ustasha Movement, (Ustaša Hrvatska Revolucionarna Organizacija, Croatian Revolutionary Movement). On 20 April 1929, Pavelić and one of his followers, Gustav Perčeć, travelled to Sofia to negotiate with Mihailov. According to Piacentini's report, the two Croatian leaders and Mihailov agreed that living as a minority under the Yugoslavian regime had been unbearable so the Croatians and the Macedonians must unify their forces to gain independence. ${ }^{69}$ The best known result of their cooperation was the assassination of Alexander I in Marseille on 9 October 1934. The IMRO was compromised in the action, despite the fact that the organization had already been dissolved by that time.

In December 1929, considering that the two factions of the IMRO would never be reunified, Italy decided to approach the Mihailovists. This did not mean leaving the Protogerovists but Grandi wanted to establish friendly relations with both of the Macedonian groups. With this approach, the relationship between the IMRO and Italy was consolidated. ${ }^{70}$ Some months later, Hory and Mussolini negotiated on the Macedonian question, and Hory - by the order of the Hungarian Military attaché, Jenö Ruszkay - suggested to harmonize Hungarian and Italian policy regarding the Macedonian question and organize support from Budapest as Hungary had a longer history with the IMRO. However, seeing the disintegration of the party, Mussolini thought that Hungary and Italy should only observe the activity of the IMRO from a certain distance. Nevertheless, Mussolini formed a section in the Chigi Palace ${ }^{71}$ with the function of monitoring Macedonian and Croatian affairs. ${ }^{72}$ Hory tried to convince Mussolini to give more valuable support to the IMRO saying that this was the most appropriate organization to focus the world's attention on

65 ASMAE, Affari Politici 1919-1930. Bulgaria. Busta 924. Telegramma 132. Piacentini to Mussolini, 4 December 1928.

66 SOKCSEVITS, Dénes. Horvátország a 7. századtól napjainkig. Budapest : Mundus Novus Kiadó, 2011 , p. 492.

67 ASMAE, Affari Politici 1919-1930. Bulgaria. Busta 927. Telegramma 1069/216. Liebmann to Mussolini, 11 September 1929.

68 DDI, Settima serie, Vol. 7, Document 574, Piacentini to Mussolini, 2. August 1929 and MNL OL, K 64. 34. csomó. 16. a tétel. 95 pol. 1928. Kiss to Walko, 27 August 1928.

69 ASMAE, Affari Politici 1919-1930. Bulgaria. Busta 927. Telegramma 2010/94. Piacentini to Mussolini, 24 April 1929.

70 DDI, Settima serie, Vol. 8, Document 222, Grandi to Mussolini, 6 December 1929.

71 In 1922, it became the official residence of the Italian Minister of Foreign Affairs.

72 MNL OL, K 64. 39. csomó. 16. a tétel. 23. res. szám. 1930. Hory to Walko, 7 February 1930. 
the inner weaknesses of the Yugoslavian state. ${ }^{73}$ According to Hory, the support of the separatists had to be directed by Italy. ${ }^{74}$

In 1930, Mihailov told Ruszkay that he was not satisfied with the relations between the IMRO and Italy. He thought that the Italian politicians preferred the Protogerovists so they did not want to stand behind Mihailov. Regarding the Hungarian support given to the Macedonians, Mihailov was absolutely satisfied..$^{75}$ However, a special event made Hungary reconsider support of the IMRO, namely the assassination of Tomalewski in his own garden in December 1930. Ruszkay disapproved the slaying, obviously because of political reasons, as it damaged the authority of the IMRO. ${ }^{76}$ With Tomalewski's death, the Protogerovists lost their most valuable member. Tsar Boris called upon the two factions to end the assassinations, which were hurting not only the authority of the IMRO but also the international prestige of Bulgaria. ${ }^{77}$ Italian sources emphasized that this killing had been the strangest as the victim was murdered at his own house. ${ }^{78}$ The diminution of the IMRO's authority was contrarious with both Hungarian and the Italian interests because it could result that Bulgaria would approach Yugoslavia.

Supposedly Hungary and Italy were afraid of a causal Yugoslavian-Bulgarian approach because Belgrade was planning cooperation with the Balkan states, including Bulgaria. This cooperation would be mainly economic and from 1930, the Balkan states organized annual conferences together. These especially attracted Italy's attention as Balkan cooperation without them would have made the realization of Italian political ambitions in this region impossible. In actuality, Bulgaria was not really interested in this Balkan collaboration, so the fears of the Italian government were not justified.

At the beginning of 1931, assassinations within the IMRO continued. The Protogerovists killed Mihailovist Iordan Giurkov, whom Hungarian politicians had relations with as well. According to the Hungarian and Italian governments, this made peace between the two factions impossible. ${ }^{79}$ Ruszkay commented on the events in this way: "As for myself, I regret that the reconciliation of the two factions failed. This fight is beneficial for the Serbs as the committee [the IMRO] concentrates with all its efforts on the inner conflicts instead of Macedonia. Hungarian policy is interested in conciliating the two parties." 80

On 19 February 1931, Piacentini was glad to write to Grandi, who in the meantime had become Minister of Foreign Affairs (1929-1932), that the two fractions had conciliated as the Protogerovists withdrew and recognized Mihailov as leader of the reunified organization. ${ }^{81}$ However, one year later the fight began again when the confidant of Mihailov, Petrov was murdered.$^{82}$ After these assassinations, the IMRO's relations with Hungary and Italy became more and more estranged ${ }^{83}$, which can also be seen by the small number of

73 MNL OL, K 64. 39. csomó. 16. a tétel. 33. res. 1930. Report of Hory, 19 February 1930.

74 GULYÁS, László. A Horthy-korszak külpolitikája 3. A Károlyi-és a Gömbös-kormány külpolitikája 1931-1936. Máriabesenyő : Attraktor Kiadó, 2015, p. 35.

75 MNL OL, K 64. 39. csomó. 16. a tétel. 35 pol. res. 1930. Ruszkay to Walko, 9 September 1930.

76 MNL OL. , K 64. 39. csomó. 16. a tétel. 50 pol. res. 1930. Ruszkay to Walko, 3 December 1930.

77 MNL OL, K 64. 45. csomó. 16. a tétel. 54 pol. res. 1930. Vörnle to Walko, 30 December 1930.

78 ASMAE, Affari Politici 1931-1945. Busta 2. Telegramma 62/21. Piacentini to Mussolini, 6 January 1931.

79 ASMAE, Affari Politici 1931-1945. Busta 2. Telegramma 1477/517. 18 March 1931.

80 MNL OL, K 64. 45. csomó. 16. a tétel. 8/ pol. res. 1931. Ruszkay to Károlyi, 10 February 1931.

81 DDI, Settima serie, Vol. 10, Document 77, Piacentini to Grandi, 19 February 1931.

82 ASMAE, Affari Politici 1931-1945. Busta 5. Telegramma 3191/978. Cora to Mussolini, 24 September 1932.

83 DDI, Settima serie, Vol. 11, Document 300, Grandi to Cora, 17 March 1932. 
Hungarian and Italian documents on the support of the IMRO between 1932 and 1934. Certainly, the relations fell apart because the IMRO's actions became embarrassing to the Bulgarian Government so the organization slowly lost the support of Sofia. The result was that the IMRO could not fulfil the role - the weakening of Yugoslavia - that Hungary and Italy had asked of it. ${ }^{84}$

In 1934, a political crisis caused by the effects of the Great Depression, the general economic crisis of 1929, resulted in the organization of rightist groups that sought to create an authoritarian regime in Bulgaria. In May 1934, republican general Kimon Georghiev took command by coup. He wanted to establish an authoritarian military state and as a first step decided to break up every organization which could damage the international prestige of Bulgaria. This meant the end of the official activity of the IMRO as well. ${ }^{85}$

The IMRO's name once again appeared in international relations in 1934. After the previously mentioned assassination in Marseille, the suspected killer of King Alexander I was an IMRO member named Vlado Chernozemski but some theories say that he could not have been the real murderer ${ }^{86}$ based on the diary of Italian diplomat Pompeo Aloisi who writes that the assassination was committed by a Ustasha named Kortov. ${ }^{87}$ The fact that the IMRO was already liquidated - at least officially - by the time of the assassination also verifies this idea, which will be the topic of another study.

To sum up, it can be said that both Hungary and Italy had intensive relations with the Internal Macedonian Revolutionary Organization between 1927 and 1934. The primary role of the IMRO in their foreign policy and in Hungarian-Italian relations was weakening the Yugoslavian state in order to further its disintegration. Besides the support given to Macedonians, they watched the actions of the IMRO which could have an impact on Hungarian and Italian foreign policy. Certainly, the most significant event for the two countries was the assassination of Protogerov and the splitting of the party into two factions, but they also recognized the formation of Macedonian-Croatian relations and the consequences of other, politically important acts of terror. Between 1932 and 1934, Hungarian-Italian support was not significant as the actions of the IMRO became more and more compromising not only for them, but also for the Bulgarian government.

84 ORMOS 1984, p. 89.

85 PAVLOV, Plamen - JANEV, Jordan. Bulgária rövid története a kezdetektöl napjainkig. Translated by Csíkhelyi Lenke. Budapest : Napvilág Kiadó, 2005, pp. 124-125.

86 ORMOS 1984, p. 134. And HAMERLI 2018, p. 125.

87 ALOISI, Pompeo. Journal, 25 Julliet 1932 - 14 Juin 1936. Paris : Plon, 1957, p. 225.

Cite:

HAMERLI, Petra. Italian-Hungarian Support for the Internal Macedonian Revolutionary Organization (IMRO): A Case Study on the Hungarian Role in Italy's Aspirations towards the Balkan Region during the Interwar Period. In Forum Historiae, 2021, Vol. 15, No. 1, pp. 23-34. ISSN 1337-6861.

DOI: https://doi.org/10.31577/forhist.2021.15.1.3

Hamerli Petra, Pécsi Tudományegyetem

Politikatudományi és Nemzetközi Tanulmányok Tanszék

Ifúság u. 6/d, H-7622 Pécs, Hungary

email: hamerli.petra@pte.hu 